\title{
Article \\ The Impact of Climate-Change-Related Disasters on Africa's Economic Growth, Agriculture, and Conflicts: Can Humanitarian Aid and Food Assistance Offset the Damage?
}

\author{
Go Shimada (D)
}

check for

updates

Citation: Shimada, G. The Impact of Climate-Change-Related Disasters on Africa's Economic Growth, Agriculture, and Conflicts: Can Humanitarian Aid and Food Assistance Offset the Damage? Int. J. Environ. Res. Public Health 2022, 19, 467. https://doi.org/10.3390/ ijerph19010467

Academic Editors: Mikio Ishiwatari and Daisuke Sasaki

Received: 21 November 2021 Accepted: 30 December 2021 Published: 1 January 2022

Publisher's Note: MDPI stays neutral with regard to jurisdictional claims in published maps and institutional affiliations.

Copyright: (C) 2022 by the author. Licensee MDPI, Basel, Switzerland. This article is an open access article distributed under the terms and conditions of the Creative Commons Attribution (CC BY) license (https:// creativecommons.org/licenses/by/ $4.0 /)$
School of Information and Communication, Meiji University, Chiyoda-ku, Tokyo 101-8301, Japan; go_shimada@meiji.ac.jp

\begin{abstract}
This study analyzed the impact of climate-related natural disasters (droughts, floods, storms/rainstorms) on economic and social variables. As the Africa-specific empirical literature is limited, this study used panel data from 1961-2011 on Africa. The study used a panel data regression model analysis. The results showed that climate change-related natural disasters affected Africa's economic growth, agriculture, and poverty and caused armed conflicts. Among the disasters, droughts are the main cause of negative impact, severely affecting crops such as maize and coffee and resulting in increased urban poverty and armed conflicts. In contrast, international aid has a positive effect but the impact is insignificant compared to the negative consequences of climate-related natural disasters. Cereal food assistance has a negative crowding-out effect on cereal production. International donors should review their interventions to support Africa's adaptative capacity to disasters. Government efficiency has reduced the number of deaths, and this is an area that supports Africa's adaptative efforts.
\end{abstract}

Keywords: climate change; natural disasters; agricultural production; food aid; official development assistance; conflict; poverty; cereal production; humanitarian aid

\section{Introduction}

With the increasing threat of global warming, there is a drastic increase in the number of catastrophic natural disasters. Every year, irregular and extreme weather events are reported worldwide. In 2021, Europe experienced an oppressive heatwave and was hit by devastating floods in July [1]. The magnitude of destruction was severe in Germany and Belgium, causing several deaths. In Asia, tropical cyclones have become stronger in recent years [2]. Additionally, Japan has recorded torrential rainfall, flooding, and landslides more often than before. Global warming is a worldwide phenomenon, but African countries are disproportionately punished, even though they contributed the least toward greenhouse gas emissions compared with developed countries. Therefore, do donor countries contribute sufficient aid to African countries to promote Africa's adaptive capacity? To answer this question, we must understand the extent of the collateral damage of global warming in Africa. This study analyzed the damage caused by climate-related natural disasters, such as floods, droughts, and storms. (The phenomenon of extreme temperature is not included in this study, as the frequency is shallow in Africa.) The remainder of this paper is organized as follows. Section 1 examines the current damage trends caused by climate-related natural disasters. Section 2 presents the study methods and data. Section 3 discusses the analysis results. Based on the results, the discussion is presented in Section 4. Finally, conclusions are drawn from the results and discussion.

\subsection{Background: Climate Change and Natural Disasters in Africa}

This section reviews climate change and natural disasters in Africa. Subsequently, it reviews the existing literature on the impact of climate change and related natural 
disasters [3,4]. For instance, using satellite images, Tellman et al. [5] found that the majority of the population was exposed to floods between 2000 and 2015, especially in Asia and sub-Saharan Africa. The authors also argued that their projections for 2030 indicate that a larger number of people will be exposed to flood threats.

\subsection{GDP Per Capita}

Gross domestic product (GDP) per capita helps measure the economic and social impact of climate-related natural disasters in Africa. There are several studies on the overall impact of natural disasters on economic growth, but not specific to climate-related disasters [6-10]. While there is no consensus regarding its impact on economic growth, some found a significantly negative long-term effect [11-16]. Conversely, some studies show a positive impact on economic growth as disasters promote the "Schumpeterian creative destruction" process [17-21]. According to this view, disasters promote innovation and investment, destroying existing practices, products, or services. Other studies reveal mixed results on economic growth due to natural disasters [22,23]. Therefore, it is necessary to clarify the effect of climate-related disasters in Africa.

\subsection{Agricultural Production and Aid}

The socioeconomic impact on agriculture and food security have been identified as critical sectors in the age of climate change [24]. Lesk et al. [25] found that droughts have reduced national cereal production by $9-10 \%$ in terms of impact on crop production. However, they found statistically no significant effect of floods. Nonetheless, the question arises if this is truly a global phenomenon or specific to Africa.

Africa is particularly vulnerable to climate change, as the region's adaptive capacity has certain constraints [26-30]. Notably, most farmers in Africa are small-holder farmers without adequate education or skills to adapt to warming temperatures and damages caused by natural disasters [31]. As there is limited empirical researched, this study examines the impact of climate-related disasters on African agriculture because this sector is most critical for people's livelihoods compared to other sectors. Therefore, if disasters decrease agricultural production, it increases poverty in both rural and urban areas.

In this regard, the literature does not consider social variables. Agricultural production is not determined by disasters. Other factors, such as farmers' human capital and market demand for agricultural commodities, are essential production factors [32,33]. The prior literature does not control for these social variables and may produce biased results. Therefore, this study estimated the impact of climate-related disasters by controlling for these factors.

A critical control variable is disaster relief provided by international donors, including the United Nations (UN), World Bank, and bilateral governments. Some literature is available on disaster relief based on case studies [34]. In contrast, there are few quantitative studies, especially on how disaster relief mitigates damage or contributes toward recovery [35,36]. One study [35] found that increased foreign aid resulted in higher fatality rates. According to another study [36], international aid increases social strife rather than decreasing it, promoting a new conflict over the distribution of resources.

Some studies have shown that aid increased after a disaster [7,37]. (There are some studies on the impact of domestic government aid to mitigate the damage, but not international aid (see, for example, [38]).) However, none applied an aid disaggregation approach to examine the impact of different aid types. These studies only used aggregated aid data. This is challenging because aid has a distinct impact. For instance, aid for primary education shows different results from assistance provided for infrastructure or humanitarian food aid. If this study uses aggregated aid data, it may lead to erroneous policy recommendations. For instance, assistance for infrastructural growth tends to expand in budgets compared to agricultural development aid. It is essential to distinguish between various aid types. Therefore, there is a research gap in this regard. There is no study on 
whether humanitarian aid, food aid, and other assistance forms have mitigated the damage caused by natural disasters.

\subsection{Impact on Poverty and Armed Conflict}

Regarding the impact on poverty, Kahn [6] found that the Gini coefficient is positively correlated with disaster-related deaths. As Barrett [39] discussed, food insecurity is associated with sudden catastrophe-like disasters and chronic poverty. Damage due to disasters is of two types: direct and indirect. Notably, in direct damage, the disaster itself kills people. In indirect damage, there are cases where people die not because of the disaster itself but due to displacement (i.e., losing their jobs after the disaster) and resultant poverty. Therefore, it is essential to measure the impact of such indirect consequences.

There is no consensus in the previous literature on the natural disaster-conflict nexus. Some studies found a link, whereas some others did not. For instance, O'Loughlin et al. [40] studied the link between climate variability and armed conflicts and found that, in general, extremely high temperatures are associated with greater conflict levels. They also found that the link varies depending on the conflict type and different subregions of Africa. Burke et al. [41] found a strong historical association between civil war and temperature in Africa, indicating that by 2030 armed conflict is likely to increase by approximately $54 \%$. However, Buhaug [42] argued against this nexus, reporting that the incidence of armed conflict has declined in Africa since 2002 despite rising temperature levels. Following this counterargument, Burke et al. [43] stated that there are some econometric issues in Buhaug's [42] study. (Burke also admits that the climate-conflict nexus still stands, but the nexus has weakened since 2002.)

These previous studies examined the temperature-conflict nexus. However, this nexus does not have a direct causal relationship. There are several indirect links between the two: natural disasters and vegetation. High temperatures cause crop damage, and damage occurs when the temperature is above $30^{\circ} \mathrm{C}$ or when the average temperature is above $25{ }^{\circ} \mathrm{C}$ for a prolonged period. Tolerance to high temperatures varies among crops. Therefore, these two consequences would have some social impact, such as reducing income. Consequently, such outcomes potentially lead to conflicts. The past literature did not consider the indirect causal relationship and treats the temperature-conflict link as a black box. The impact of high temperatures on vegetation was beyond the scope of this study; therefore, this research examined the impact of disasters on conflicts.

\subsection{Government Effectiveness}

Strömberg [7] studied whether government effectiveness is essential for dealing with disasters. The study used the government effectiveness index, an indicator produced by the World Bank, to test its importance of governance effectiveness. Government effectiveness is essential during disasters. At the time of a crisis, the government needed to handle everything quickly and within a limited period. Even in developed countries, handling crises after disasters is challenging and sometimes governments fail to cope with them. However, this is likely more difficult for developing countries. This raises the question: How important is government effectiveness in Africa? Strömberg found that government effectiveness reduces the number of people killed by natural disasters globally and not specifically in Africa. This study examined the importance of government effectiveness to mitigate damage caused by climate-related disasters.

This section reviewed the current trends in climate-related natural disasters in Africa and examined the literature on the impact of disasters on GDP, agriculture, poverty and conflict, and government effectiveness.

First, based on the identified research gaps, the next section examines the impact of climate-related natural disasters and international aid on GDP per capita. Second, the nexus between disaster-agriculture is discussed, focusing on major crops. Third, the impact on poverty and conflict was tested. Finally, factors contributing to decreasing (or 
increasing) the death toll due to natural disasters were tested. One of the factors examined was international aid extended to African countries.

Based on the research gap identified in this section, the next section discusses the following. First, it overviews the impact of climate-related natural disasters and international aid on GDP per capita. Second, the nexus between the disasters-agriculture is discussed, focusing on major crops. Third, the impacts on poverty and conflicts are investigated. Finally, factors contributing to decreasing (or increasing) death tolls by natural disasters are tested. One of the factors examined is international aid extended to African countries.

\section{Methods and Data}

This section describes the analytical framework for empirical analysis. This study tested the impact of three elements of climate-related disasters on (1) GDP per capita and agricultural production, (2) impact on poverty and conflict, and (3) factors contributing toward reducing the impact of disasters.

Research gaps were identified based on the literature review in Section 1. There is no consensus on the impact of natural disasters on GDP, and there is no empirical analysis focusing on the impact of climate-related natural disasters on agricultural production in Africa. Even the literature on global agricultural production does not control for other socioeconomic conditions. Agricultural production is a part of economic activities; therefore, there is a need to control for these variables. Otherwise, there is a potential for result bias. Therefore, it is important to understand the impact of climate-related natural disasters on GDP and agricultural production, considering other socio-economic factors.

To estimate the impact on GDP per capita growth, the following formula was used, following the model used by Skidmore and Toya [20].

$$
\Delta\left(\frac{Y}{P}\right)_{i, t}=\alpha_{i, t}+\beta_{1} \Delta\left(\frac{Y}{P}\right)_{i, t-1}+\beta_{2} \operatorname{Dis}_{i, t}+\beta_{3} \operatorname{Aid}_{i, t}+\beta_{4} \operatorname{Gov}_{i, t}+\beta_{5} X_{i, t}+\varepsilon_{i, t}
$$

$Y$ denotes GDP and $P$ represents the population. Therefore, $\Delta\left(\frac{Y}{P}\right)_{i, t}$ is GDP per capita growth, $i$ is a country index to capture country-specific effects, and $t$ is the time (year) index. The lagged GDP per capita growth $\left(\Delta\left(\frac{Y}{P}\right)_{i, t-1}\right)$ is included because the previous year's growth trend greatly affects the current year's economic activities. Dis $s_{i, t}$ is a measure of the impact of disasters specific to country $i$ at time $t$. This study used the number of people affected by disasters for this variable. This is because these data represent the impact of disasters. The number of occurrences does not necessarily equate to the impact. If a disaster occurs in an uninhabited area, then the impact on human activities is limited, as people do not live there. Aid denotes international aid. This is global official development assistance (ODA) data and not a specific country's ODA. This study used a different type of aid data, as impact varies depending on the aid type. For instance, the impact of cereal food aid is not the same as a medical aid. Therefore, it is necessary to disaggregate aid data. This study used the following data: aid for agriculture, humanitarian aid, and cereal food aid. $\operatorname{Gov}_{i, t}$ denotes government expenditure. $X_{i, t}$ are the other control variables, including the following variables: education, fertility rate, and government effectiveness index. The education variable represents human capital [32-44]. This study used the government effectiveness index developed by the World Bank, which measures the quality of public services, infrastructure, and civil service based on the World Bank's survey [45].

The following analytical framework will be used to estimate the impacts on agricultural production, reformulating Equation (1) to focus on agriculture.

$$
A g r_{i, t}=\alpha_{i, t}+\beta_{1} D i s_{i, t}+\beta_{2} \Delta\left(\frac{Y}{P}\right)_{i, t}+\beta_{3} A i d_{i, t}+\beta_{4} X_{i, t}+\varepsilon_{i, t}
$$

$A g r_{i, t}$ denotes the variable for agricultural production. $D i s_{i, t}, \Delta\left(\frac{Y}{P}\right)_{i, t}$ and $A i d_{i, t}$ indicate the same as the above equation. $\Delta\left(\frac{Y}{P}\right)_{i, t}$ is included because agricultural production is affected by economic activities. $X_{i, t}$ denotes other control variables, such as inequality in 
educational attainment and the government effectiveness variable. The former represents human capital.

As this estimation used panel data, three methods were used to assess the results. (This study used Stata/SE 17.0 for the estimation.) They estimate fixed effects (FE), random effects (RE), and pooling. Among the three estimation methods, the most appropriate estimation method is determined by the results of the F-test, Hausman test, and the Breusch-Pagan test. The method determined for each model is reported at the bottom of the result tables.

Table 1 shows the descriptive statistics of the data used in the empirical study. This dataset covers 90 African countries (including both sub-Saharan African and North African countries). This is unbalanced panel data. The period varies depending on the data, and they are annual data with gaps. This dataset was constructed using the following four datasets.

Table 1. Descriptive Statistics.

\begin{tabular}{|c|c|c|c|c|c|c|c|}
\hline Variable & Obs. & Mean & Std. Dev. & Min. & Max. & Year & Data Source \\
\hline $\begin{array}{l}\text { Number of People Affected } \\
\text { by Climate-related Disasters }\end{array}$ & 3394 & $171,620.9$ & $906,675.7$ & 0 & $23,000,000$ & 1900-2021 & EM-DAT \\
\hline $\begin{array}{c}\text { Number of People Affected } \\
\text { by Drought }\end{array}$ & 3143 & 0.0140703 & 0.080764 & 0 & 1 & 1900-2021 & EM-DAT \\
\hline $\begin{array}{c}\text { Number of People Affected } \\
\text { by Flood }\end{array}$ & 3143 & 0.0024037 & 0.0179437 & 0 & 0 & 1927-2021 & EM-DAT \\
\hline $\begin{array}{c}\text { Number of People Affected } \\
\text { by Storm }\end{array}$ & 3143 & 0.0012416 & 0.0250523 & 0 & 1 & 1948-2021 & EM-DAT \\
\hline $\begin{array}{l}\text { Number of Deaths by } \\
\text { Climate-related Disasters }\end{array}$ & 3394 & 267.0533 & 6475.562 & 0 & 300,000 & 1900-2021 & EM-DAT \\
\hline Control of Corruption & 1185 & -0.542972 & 0.687297 & -1.869 & 2 & 1996-2019 & V-Dem \\
\hline Local Government Index & 3224 & 0.4376833 & 0.3243581 & 0 & 1 & 1900-2020 & V-Dem \\
\hline Educational Inequality, Gini & 2283 & 60.83778 & 22.18283 & 11.875 & 99.804 & 1927-2010 & V-Dem \\
\hline Net ODA & 2286 & 10.48105 & 11.82156 & -0.251879 & 147 & 1960-2011 & WDI \\
\hline Humanitarian ODA & 503 & $66,800,000$ & $171,000,000$ & 1387 & $1,380,000,000$ & 2002-2011 & WDI \\
\hline $\begin{array}{l}\text { ODA for reconstruction relief } \\
\text { and rehabilitation }\end{array}$ & 296 & $5,796,040$ & $13,200,000$ & $-52,185$ & $96,900,000$ & 2002-2011 & WDI \\
\hline ODA for Agriculture & 513 & $29,000,000$ & $40,400,000$ & 7069 & $387,000,000$ & 2002-2011 & WDI \\
\hline Emergency ODA & 493 & $64,100,000$ & $165,000,000$ & 1387 & $1,280,000,000$ & 2002-2011 & WDI \\
\hline $\begin{array}{l}\text { ODA for Disaster Prevention } \\
\text { and Preparedness }\end{array}$ & 249 & $1,209,090$ & $2,266,356$ & $-75,420$ & $16,700,000$ & 2002-2011 & WDI \\
\hline Cereal Food Aid & 1309 & $67,786.64$ & 165,895 & 0 & $1,900,805$ & 1988-2012 & WDI \\
\hline Agriculture Production Index & 2583 & 70.33316 & 28.66801 & 13.42 & 193 & 1961-2011 & WDI \\
\hline Cereal Production Index & 2512 & 82.68087 & 77.53881 & 5.79 & 1925 & 1961-2011 & WDI \\
\hline Maize Production (ton) & 1950 & $584,838.4$ & $1,210,479$ & 4 & $10,500,000$ & 1961-2019 & FAOSTAT \\
\hline Sorghum Production (ton) & 1522 & $245,611.4$ & $506,910.9$ & 0 & $5,265,580$ & 1961-2019 & FAOSTAT \\
\hline Millet Production (ton) & 1323 & $131,864.3$ & $262,178.4$ & 54 & $1,878,527$ & 1961-2019 & FAOSTAT \\
\hline Rice Production (ton) & 1669 & $372,630.1$ & $938,768.1$ & 0 & $7,253,373$ & 1961-2019 & FAOSTAT \\
\hline Wheat Production (ton) & 1105 & 607,994 & $1,521,939$ & 0 & $9,607,736$ & 1961-2019 & FAOSTAT \\
\hline Barley Production (ton) & 552 & $449,506.7$ & $749,312.6$ & 100 & $3,831,130$ & 1961-2019 & FAOSTAT \\
\hline Fonio Production (ton) & 381 & $36,381.73$ & $83,020.09$ & 100 & 530,227 & 1961-2020 & FAOSTAT \\
\hline $\begin{array}{l}\text { Poverty gap at the urban } \\
\text { poverty line }(\%)\end{array}$ & 76 & 11.90395 & 9.049087 & 1.8 & 40 & 1961-2011 & WDI \\
\hline $\begin{array}{l}\text { Poverty gap at the rural } \\
\text { poverty line }(\%)\end{array}$ & 77 & 22.07273 & 9.499953 & 3.6 & 53 & 1961-2012 & WDI \\
\hline $\begin{array}{c}\text { Battle-related deaths (number } \\
\text { of people) }\end{array}$ & 278 & 1411.522 & 4618.351 & 0 & 50,293 & 1961-2013 & WDI \\
\hline
\end{tabular}

First, the Emergency Events Database (EM-DAT) was used for natural disaster-related data [46]. The EM-DAT is an international disasters' database widely used to analyze natural disasters and has been managed by the Center for Research on the Epidemiology of Disasters (CRED) since 1988. For disasters to be recorded as an extreme event, one of the following criteria must be met: (1) 10 or more people reportedly killed, (2) 100 or more people affected, (3) a declaration of a state of emergency, and (4) a call for international assistance.

Second, the WDI (World Development Indicators) dataset is compiled by the World Bank [45]. The Food and Agriculture Organization Corporate Statistical Database (FAO- 
STAT) is a dataset on agricultural production provided by the Food and Agriculture Organization (FAO) [47]. Finally, the V-dem is used, produced by the Varieties of Democracy Project on government effectiveness and educational inequality data [48].

Five types of variables are used as measures for disaster impact. The four variables represent the number of people affected by the following: (1) climate-related disasters (aggregate variable), (2) droughts, (3) floods, and (4) storms. The variable of climate-related disasters is the aggregate variable of droughts, floods, and storms. This study also used the number of deaths caused by climate-related disasters. In addition, this study used two other variables: corruption control and the local government index as measures of government effectiveness. If corruption control is inadequate, the government's effectiveness is considered low and would affect the implementation of recovery after a disaster. For international aid, seven different types of data were prepared to examine how aid works to mitigate the impact of natural disasters. The aid for agricultural development works differently from humanitarian aid. For agricultural production, the agricultural production index is the aggregate index. Production data for major cereals, such as maize, sorghum, and millet, were used to examine the impact of crops.

\section{Results}

This section reviews the current trends of natural disasters in Africa before analyzing the impacts of natural disasters. Figure 1 shows the number of people affected by droughts, floods, and storms caused by climate change. The data used the Emergency Events Database (EM-DAT), mentioned in the previous section [4]. As a measure of natural disasters, Figure 1 uses the number of people affected rather than the number of disasters that occurred because this is a better measure of disaster severity. Each disaster is different in scale and impact. If a disaster occurs in a remote mountainous area, the social impact is less, but the same type of event would have a devastating effect in an urban area. Therefore, Figure 1 shows the number of people affected, rather than the number of occurrences.

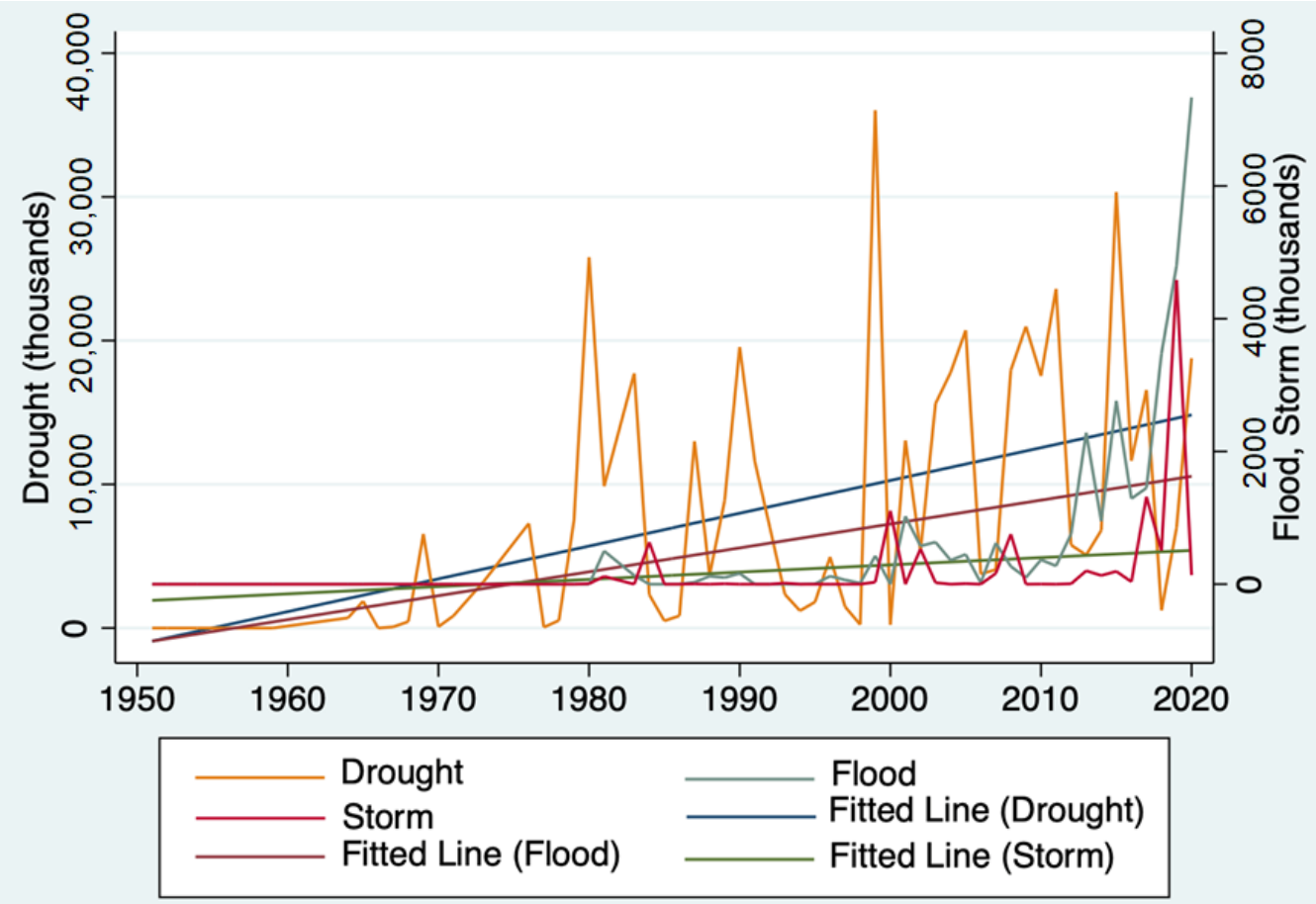

(Source: Developed by the author based on EM-DAT(2021))

Figure 1. The total number of people affected by droughts, floods, and storms in Africa. 
Furthermore, an essential point must be considered when interpreting these numbers. The disaster number, such as the number of people affected by a disaster, may be underreported compared with the actual situation [7]. For instance, some authoritarian African regimes may underreport the damage caused by disasters to avoid being criticized for their response. Given African governments' capacity for data authenticity, there may be misreporting across countries and over time [49]. In such a case, there is an underlying risk of underestimating the significance of the impact of climate-related disasters.

Figure 1 has two axes because the damage caused by droughts is much larger than that caused by floods and storms. The left axis represents the total number of people affected by droughts, and the right axis shows the number of people displaced by floods and storms. The worst drought affected more than 35,000 people in 1999. However, on the other hand, the impact of floods and storms is much lower than the drought. Due to the nature of disasters, all three lines, representing each natural disaster, fluctuate significantly. For instance, there was a massive drought in 1999, but there was no drought before and after the year. The damage caused by droughts was not significant until the late 1960s, and they seem to occur quite often now. A similar pattern can be observed for floods and storms. However, during the late 1990s, there was an unprecedented increase in the number of people affected by floods and storms.

To clearly understand the long-term trend of natural disasters, fitted lines for drought, floods, and storms are drawn in Figure 1. These three fitted lines show a clear upward trend, especially due to droughts, followed by floods and storms. Therefore, as Figure 1 confirms, the damage caused by climate-related disasters has increased rapidly since the late 1960s, primarily during droughts. Therefore, the next question is how disaster-related damage affects Africa's socio-economic development and growth.

Table 2 presents the estimated coefficients in the impact on GDP per capita growth, and the difference among the four models is the difference of data used. Models 1 and 2 used aggregate disaster measures (number of people affected by climate-related disasters) and Models 3 and 4 used disaggregated disaster variables (droughts, floods, and storms). As the dataset is unbalanced panel data with gaps, the $N$ used for estimation differs depending on the variable used. Models 1 and 2 show that climate-related natural disasters significantly lowered GDP per capita growth. However, as Models 3 and 4 show, the impact differs depending on the natural disaster type. Only droughts had a statistically significant negative impact, as opposed to floods and storms. This indicates the importance of any drought policy to sustain GDP per capita growth in Africa.

Models 1 and 3 examined the impact of humanitarian ODA on GDP per capita. How do global efforts mitigate the negative impact of natural disasters? Similar to Models 2 and 4, which examined the emergency aid, all these variables became insignificant. This is reasonable considering that, compared with the size of a country's GDP, the amount of aid in these categories is too small to capture the impact. Therefore, the study next examined aid impact focusing on crops because the agricultural sector is particularly vulnerable to natural disasters, affecting economic growth and damaging crop production.

Table 3 examines the impact on agricultural production. The number of people affected by natural disasters, an aggregate variable, is used to measure disaster impact. This variable is statistically significant, and the negative coefficient is also substantial. This result indicates that climate-related disasters have a significant negative impact on agricultural production. Educational inequality is also negative. Therefore, human capital is important for agricultural production. As the educational Gini coefficient reflects income inequality, the widening rich-poor gap negatively impacts agricultural production. This is consistent with past studies [32,33]. Therefore, human capital is required to cope with disasters caused by climate change, which are likely to increase in the future. 
Table 2. Economic Growth Impacts by Climate-related Disasters and Aid.

\begin{tabular}{|c|c|c|c|c|}
\hline \multirow{2}{*}{ Dependent Variable } & \multicolumn{4}{|c|}{ GDP Per Capita Growth (Annual \%) } \\
\hline & (1) & (2) & (3) & (4) \\
\hline Lagged GDP per capita growth & $\begin{array}{l}0.1694751^{* * *} \\
\quad(2.80)\end{array}$ & $\begin{array}{l}0.1543027 * * \\
(2.49)\end{array}$ & $\begin{array}{l}0.16712^{* * *} \\
\quad(2.75)\end{array}$ & $\begin{array}{l}0.1519377^{* *} \\
\quad(2.44)\end{array}$ \\
\hline Education (+15 years old) & $\begin{array}{l}-1.228877 \\
(-0.56)\end{array}$ & $\begin{array}{l}-1.139392 \\
(-0.52)\end{array}$ & $\begin{array}{c}-1.25669 \\
(-0.58)\end{array}$ & $\begin{array}{l}-1.172042 \\
(-0.53)\end{array}$ \\
\hline Fertility Rate & $\begin{array}{c}1.35599 \\
(0.66) \\
\end{array}$ & $\begin{array}{c}2.05509 \\
(0.97) \\
\end{array}$ & $\begin{array}{l}1.479018 \\
(0.71) \\
\end{array}$ & $\begin{array}{c}2.180705 \\
(1.02)\end{array}$ \\
\hline HDI & $\begin{array}{c}-3.463914 \\
(-0.17)\end{array}$ & $\begin{array}{c}-0.953797 \\
(-0.04)\end{array}$ & $\begin{array}{c}-2.788904 \\
(-0.13)\end{array}$ & $\begin{array}{c}-0.2467038 \\
(-0.01)\end{array}$ \\
\hline $\begin{array}{c}\text { Number of People Affected by } \\
\text { Climate-related Disasters }\end{array}$ & $\begin{array}{c}-8.057152^{* *} \\
(-2.07)\end{array}$ & $\begin{array}{l}-8.057298 * * \\
(-2.05)\end{array}$ & & \\
\hline Number of People Affected by Drought & & & $\begin{array}{l}-7.632749 * \\
\quad(-1.87)\end{array}$ & $\begin{array}{c}-7.614573 * \\
(-1.85)\end{array}$ \\
\hline Number of People Affected by Flood & & & $\begin{array}{c}-13.04042 \\
(-0.99)\end{array}$ & $\begin{array}{c}-13.28393 \\
(-1.01)\end{array}$ \\
\hline Number of People Affected by Storm & & & $\begin{array}{c}0.00000684 \\
(1.05)\end{array}$ & $\begin{array}{l}0.00000685 \\
\quad(1.05)\end{array}$ \\
\hline Government Expenditure & $\begin{array}{l}0.1529741 \\
\quad(1.53)\end{array}$ & $\begin{array}{c}0.1360603 \\
(1.31)\end{array}$ & $\begin{array}{l}0.1624341 \\
\quad(1.62)\end{array}$ & $\begin{array}{l}0.1460737 \\
\quad(1.40)\end{array}$ \\
\hline Humanitarian ODA & $\begin{array}{l}-0.0000000007 \\
(-0.14)\end{array}$ & & $\begin{array}{c}-0.000000001 \\
(-0.14)\end{array}$ & \\
\hline Emergency ODA & & $\begin{array}{c}-0.000000001 \\
(-0.180)\end{array}$ & & $\begin{array}{c}-0.000000001 \\
(-0.18)\end{array}$ \\
\hline Constant & $\begin{array}{c}1.043053 \\
(0.06)\end{array}$ & $\begin{array}{c}-3.935066 \\
(-0.22)\end{array}$ & $\begin{array}{c}0.1118494 \\
(0.01)\end{array}$ & $\begin{array}{c}-4.888921 \\
(-0.28)\end{array}$ \\
\hline$N$ & 272 & 264 & 272 & 264 \\
\hline Type of Regression & $\mathrm{FE}$ & $\mathrm{FE}$ & $\mathrm{FE}$ & $\mathrm{FE}$ \\
\hline
\end{tabular}

Note: Numbers in parentheses are $t$-values; ${ }^{* * *}, * *$ and ${ }^{*}$ indicate statistical significance at the $1 \%, 5 \%$, and $10 \%$ levels, respectively.

According to Models 1 and 4, humanitarian aid and ODA for disaster prevention and preparedness are not statistically significant. In contrast, according to Models 2 and 3 , agricultural aid is positive. These results are consistent with the expected outcome, as humanitarian aid and disaster prevention assistance do not support agricultural production. However, this analysis shows that disasters have a substantial negative impact on agricultural production. Therefore, agricultural aid has become even more important during the age of global warming, specifically to fight against the long-term negative consequences. However, it is necessary to note that the coefficient of agricultural aid is small, indicating that agricultural aid alone is not enough to mitigate the negative impact of climate-related disasters. 
Table 3. Impact on Agricultural Production by Climate-related Disasters and Aid.

\begin{tabular}{|c|c|c|c|c|}
\hline \multirow{2}{*}{ Dependent Variable } & \multicolumn{4}{|c|}{ Agriculture Production Index } \\
\hline & (1) & (2) & (3) & (4) \\
\hline GDP per capita growth & $\begin{array}{c}-0.0003642 \\
(-0.00)\end{array}$ & $\begin{array}{c}-0.1086933 \\
(-0.95)\end{array}$ & $\begin{array}{c}-0.115295 \\
(-0.99)\end{array}$ & $\begin{array}{c}-0.032736 \\
(-0.10)\end{array}$ \\
\hline $\begin{array}{c}\text { Number of People Affected by Climate-related } \\
\text { Disasters }\end{array}$ & $\begin{array}{c}-24.41415^{* * *} \\
(-2.74)\end{array}$ & $\begin{array}{l}-23.02236^{* * *} \\
(-2.58)\end{array}$ & $\begin{array}{l}-21.84345^{* *} \\
(-2.41)\end{array}$ & $\begin{array}{l}-35.02979 * * \\
(-2.06)\end{array}$ \\
\hline Educational Inequality, Gini & $\begin{array}{l}-4.608486^{* * *} \\
(-19.84)\end{array}$ & $\begin{array}{l}-4.224185^{* * *} \\
(-15.48)\end{array}$ & $\begin{array}{l}-4.253704^{* * *} \\
(-15.29)\end{array}$ & $\begin{array}{c}-6.260741^{* * *} \\
(-6.89)\end{array}$ \\
\hline Humanitarian ODA & $\begin{array}{l}-0.0000000052 \\
(-0.47)\end{array}$ & & & \\
\hline ODA for Agriculture & & $\begin{array}{l}0.000000075^{* * *} \\
(2.65)\end{array}$ & $\begin{array}{l}0.000000076^{* * *} \\
(2.66)\end{array}$ & \\
\hline $\begin{array}{l}\text { ODA for disaster prevention \& preparedness } \\
\text { (lagged) }\end{array}$ & & & & $\begin{array}{l}-0.0000008 \\
(-0.95)\end{array}$ \\
\hline Local Government Index & & & $\begin{array}{c}-8.470382 \\
(-1.35)\end{array}$ & $\begin{array}{c}3.579998 \\
(0.14)\end{array}$ \\
\hline Constant & $\begin{array}{l}319.1347^{* * *} \\
(29.24)\end{array}$ & $\begin{array}{l}297.3906^{* * *} \\
(22.74)\end{array}$ & $\begin{array}{l}303.5181 * * * \\
(21.33)\end{array}$ & $\begin{array}{l}397.2466^{* * *} \\
(9.78)\end{array}$ \\
\hline$N$ & 370 & 379 & 370 & 120 \\
\hline Type of Regression & FE & FE & FE & FE \\
\hline
\end{tabular}

Note: Numbers in parentheses are $t$-values; ${ }^{* * *}$, and ${ }^{* *}$ indicate statistical significance at the $1 \%$, and $5 \%$ levels, respectively.

Table 4. Impact on Agricultural Production by Climate-related Disasters and Aid.

\begin{tabular}{|c|c|c|c|}
\hline \multirow{2}{*}{ Dependent Variable } & \multicolumn{3}{|c|}{ Agriculture Production Index } \\
\hline & (1) & (2) & (3) \\
\hline GDP per capita growth & $\begin{array}{c}-0.0106388 \\
(-0.09) \\
\end{array}$ & $\begin{array}{c}-0.1173564 \\
(-1.01) \\
\end{array}$ & $\begin{array}{l}0.3344108^{* * *} \\
(5.03)\end{array}$ \\
\hline Number of People Affected by Climate-related Disasters & $\begin{array}{c}-23.4604^{* * *} \\
(-2.58)\end{array}$ & & \\
\hline Number of People Affected by Flood & & $\begin{array}{c}-17.48007 \\
(-0.41)\end{array}$ & $\begin{array}{c}-9.036425 \\
(-0.30)\end{array}$ \\
\hline Number of People Affected by Drought & & $\begin{array}{c}-24.51023^{* * *} \\
(-2.61)\end{array}$ & $\begin{array}{c}-12.51029^{*} \\
(-1.94) \\
\end{array}$ \\
\hline Number of People Affected by Storm & & $\begin{array}{l}-0.000009 \\
(-0.93)\end{array}$ & $\begin{array}{c}-0.000007 \\
(-1.57) \\
\end{array}$ \\
\hline Educational Inequality, Gini & $\begin{array}{c}-4.64529^{* * *} \\
(-19.48) \\
\end{array}$ & $\begin{array}{c}-4.230962^{* * *} \\
(-15.09)\end{array}$ & $\begin{array}{c}-2.568219^{* * *} \\
(-26.68)\end{array}$ \\
\hline Local Government Index & $\begin{array}{c}-8.113644 \\
(-1.30)\end{array}$ & $\begin{array}{c}-8.025702 \\
(-1.28)\end{array}$ & $\begin{array}{l}20.9569^{* * *} \\
\quad(6.93)\end{array}$ \\
\hline Emergency ODA & $\begin{array}{c}-0.000000003 \\
(-0.775)\end{array}$ & & \\
\hline ODA for Agriculture & & $\begin{array}{l}0.00000008^{* * *} \\
(2.70)\end{array}$ & \\
\hline Cereal Food Aid & & & $\begin{array}{c}-0.0000148^{* * * *} \\
(-3.49)\end{array}$ \\
\hline Constant & $\begin{array}{c}326.9576^{* * *} \\
(26.54)\end{array}$ & $\begin{array}{l}302.2468^{* * *} \\
(21.07)\end{array}$ & $\begin{array}{l}206.6968^{* * *} \\
\quad(37.24)\end{array}$ \\
\hline $\begin{array}{c}N \\
\text { Type of Regression }\end{array}$ & $\begin{array}{l}355 \\
\mathrm{FE}\end{array}$ & $\begin{array}{l}370 \\
\mathrm{FE}\end{array}$ & $\begin{array}{c}958 \\
\mathrm{FE}\end{array}$ \\
\hline
\end{tabular}

Note: Numbers in parentheses are $t$-values; ${ }^{* * *}$ and * indicate statistical significance at the $1 \%$, and $10 \%$ levels, respectively. 
Table 4 investigates the impact of climate-related disasters on agriculture. Compared to Table 3, the impact of different types of aid is tested in Table 4. Models 1, 2, and 3 examine emergency aid, agricultural aid, and cereal food aid, respectively. Emergency aid is not significant, similar to humanitarian aid. This is expected because emergency aid does not aim at agricultural development. The impact on agricultural aid and cereal food aid is in the opposite direction, wherein agricultural aid is positive but cereal food aid is negative due to a substitutional effect. The inflow of cereals from foreign countries seems to have a crowding-out effect on domestically produced cereals. For agricultural aid, even if the coefficient is positive, it is very small and unremarkable compared to the coefficient of disasters. In other words, agricultural aid does not compensate for the negative impact of disasters. The results for the impact of disasters and educational inequality are the same as those in Table 3, further confirming the earlier results.

Tables 5 and 6 examine the impact on a crop-by-crop basis. The difference between these two tables is that Table 5 includes ODA for agriculture, whereas Table 6 examines the impact of cereal aid. This analysis shows that the impact varies by crop. For instance, droughts negatively impact maize. Storms reduce rice and fonio production because, at the heading stage, strong winds can topple the panicles of rice and fonio. Floods also reduce fonio production. However, this result is not robust, as these crops are statistically insignificant (Table 6). Therefore, the impact of disasters on crops varies depending on the vegetation type.

Agricultural ODA has a positive impact on maize, sorghum, millet, and rice, but the impact differs by crop. Furthermore, the coefficient is very small. More importantly, it can be observed in Table 6 that the impact of cereal aid is different from agricultural ODA. Overall, cereal aid has a negative impact, but this influence differs depending on the crop. Maize, sorghum, rice, and wheat are all negatively affected, but millet production increases marginally. However, the reason for increased millet production is unclear, but millet may be used as a substitute for cereals such as wheat, whose production decreased. In many cases, cereal aid is provided during humanitarian crises, including natural disasters. However, cereal aid can negatively affect production because cereals provided through food aid have a crowding-out effect on domestic production.

This study also examined non-cereal crops, such as bananas, cassava, tea, and coffee (Appendix A). It can be observed that only coffee is negatively and strongly affected by droughts because water stress affects coffee production due to water availability sensitivity.

As discussed above, natural disasters negatively impact agricultural production. The next question is what are the consequences of such effects. Table 7 examines the impact of climate-related disasters on poverty and conflicts because reduced agricultural production indicates lower income for farmers. This would probably impact poverty and conflicts. As observed in Section 1 (Literature review), previous studies examine the temperatureconflict link without considering the internal mechanism. As discussed, using disaster data, this study examined the internal nexus between climate change and armed conflicts.

Model 1 examined the impact of aggregate climate-related natural disasters in rural areas and shows that poverty does not increase in rural areas. The growth in GDP per capita reduces poverty in rural areas. However, this situation contrasts in urban areas, where climate-related natural disasters increase poverty. This is probably because people migrate from rural to urban areas in search of jobs after natural disasters occur. Therefore, rather than rural areas, poverty increases in urban areas. Model 3 analyzes the impact of different disaster types, focusing only on urban areas. The results show that climate variability that leads to extreme events such as droughts causes a substantial increase in poverty in Africa. 
Table 5. Impact on Cereal Production by Climate-related Disasters and Aid

\begin{tabular}{|c|c|c|c|c|c|c|c|c|}
\hline \multirow[b]{2}{*}{ Dependent Variable } & (1) & (2) & (3) & (4) & (5) & (6) & (7) & (8) \\
\hline & $\begin{array}{l}\text { Cereal Production } \\
\text { Index }\end{array}$ & Maize Production & $\begin{array}{l}\text { Sorghum } \\
\text { Production }\end{array}$ & Millet Production & Rice Production & Wheat Production & Barley Production & Fonio Production \\
\hline GDP per capita growth & $\begin{array}{c}0.3519966 \\
(1.22)\end{array}$ & $\begin{array}{c}1591.614 \\
{[0.41]}\end{array}$ & $\begin{array}{c}-1304.271 \\
(-0.74)\end{array}$ & $\begin{array}{c}830.9917 \\
(0.62)\end{array}$ & $\begin{array}{c}-1334.704 \\
{[-0.45]}\end{array}$ & $\begin{array}{c}9952.268 \\
{[1.06]}\end{array}$ & $\begin{array}{c}24,650.14 \\
{[0.80]}\end{array}$ & $\begin{array}{c}-2459.17 \\
(-1.21)\end{array}$ \\
\hline $\begin{array}{l}\text { Educational Inequality, } \\
\text { Gini }\end{array}$ & $\begin{array}{l}-7.099192 * * * \\
(-10.44)\end{array}$ & $\begin{array}{c}-32,610.23 \text { *** } \\
{[-5.19]} \\
\end{array}$ & $\begin{array}{c}-5121.155 \\
(-1.58)\end{array}$ & $\begin{array}{c}-989.7303 \\
(-0.40) \\
\end{array}$ & $\begin{array}{c}-8121.831 \\
{[-1.37]}\end{array}$ & $\begin{array}{c}-8631.816 \\
{[-0.54]}\end{array}$ & $\begin{array}{c}-1084.82 \\
{[-0.05]}\end{array}$ & $\begin{array}{l}-12,828.91^{* * *} \\
(-8.28)\end{array}$ \\
\hline $\begin{array}{l}\text { Number of People } \\
\text { Affected by Flood }\end{array}$ & $\begin{array}{l}-4.82892 \\
(-0.05]) \\
\end{array}$ & $\begin{array}{c}-910,600.5 \\
{[-0.46]}\end{array}$ & $\begin{array}{l}27,443.77 \\
(0.03) \\
\end{array}$ & $\begin{array}{c}-35,073.24 \\
(-0.06)\end{array}$ & $\begin{array}{c}-223,888.4 \\
{[-0.16]} \\
\end{array}$ & $\begin{array}{c}1,576,617 \\
{[0.19]}\end{array}$ & $\begin{array}{c}-1,673,180 \\
{[-0.07]} \\
\end{array}$ & $\begin{array}{l}-745,509.2^{* * *} \\
(-2.92)\end{array}$ \\
\hline $\begin{array}{l}\text { Number of People } \\
\text { Affected by Storm }\end{array}$ & $\begin{array}{c}0.000000779 \\
(0.03)\end{array}$ & $\begin{array}{c}-0.1388403 \\
{[-0.64]}\end{array}$ & $\begin{array}{c}-0.0418895 \\
(-0.44)\end{array}$ & $\begin{array}{c}-0.1643853 \\
(-0.62)\end{array}$ & $\begin{array}{c}-0.66323 * * * \\
{[-2.77]}\end{array}$ & $\begin{array}{c}-0.0056365 \\
{[-0.01]}\end{array}$ & $\begin{array}{c}0.0449533 \\
{[0.01]}\end{array}$ & $\begin{array}{c}-51.86224 * \\
(-1.92)\end{array}$ \\
\hline ODA for Agriculture & $\begin{array}{c}0.000000116^{*} \\
(1.65)\end{array}$ & $\begin{array}{l}0.0040394 * * * \\
\quad[5.45]\end{array}$ & $\begin{array}{c}0.001325^{* * *} \\
(3.95)\end{array}$ & $\begin{array}{l}0.000796^{* * *} \\
(3.19)\end{array}$ & $\begin{array}{c}0.0034716^{* * *} \\
{[5.11]}\end{array}$ & $\begin{array}{c}0.0011092 \\
{[0.53]}\end{array}$ & $\begin{array}{c}0.0014411 \\
{[0.42]}\end{array}$ & $\begin{array}{c}-0.0003032 \\
(-2.39) \\
\end{array}$ \\
\hline Constant & $\begin{array}{l}433.7546^{* * *} \\
(13.19)\end{array}$ & $\begin{array}{c}2,230,139 * * * \\
{[5.79]}\end{array}$ & $\begin{array}{l}461,934.9^{* * *} \\
(2.82)\end{array}$ & $\begin{array}{c}208,877.2 \\
(1.55) \\
\end{array}$ & $\begin{array}{l}866,423.4^{* *} \\
{[2.43]}\end{array}$ & $\begin{array}{c}1,128,003 \\
{[1.32]} \\
\end{array}$ & $\begin{array}{c}400,714.1 \\
{[0.36]} \\
\end{array}$ & $\begin{array}{l}1,043,952 \text { *** } \\
(8.78)\end{array}$ \\
\hline $\begin{array}{c}N \\
\text { Type of Regression }\end{array}$ & $\begin{array}{l}373 \\
\mathrm{FE}\end{array}$ & $\begin{array}{l}247 \\
\mathrm{FE}\end{array}$ & $\begin{array}{l}324 \\
\mathrm{RE}\end{array}$ & $\begin{array}{l}185 \\
\mathrm{FE} \\
\end{array}$ & $\begin{array}{l}332 \\
\mathrm{RE}\end{array}$ & $\begin{array}{l}158 \\
\mathrm{RE}\end{array}$ & $\begin{array}{l}62 \\
\mathrm{RE}\end{array}$ & $\begin{array}{l}45 \\
\mathrm{FE} \\
\end{array}$ \\
\hline \multicolumn{9}{|c|}{ Note: Numbers in brackets are $z$-values, and in parentheses are $t$-values; $* * *, * *$, and $*$ indicate statistical significance at the $1 \%, 5 \%$, and $10 \%$ levels, respectively. } \\
\hline \multirow[b]{2}{*}{ Dependent Variable } & (1) & (2) & (3) & (4) & (5) & (6) & (7) & (8) \\
\hline & $\begin{array}{c}\text { Cereal } \\
\text { Production Index }\end{array}$ & Maize Production & $\begin{array}{l}\text { Sorghum } \\
\text { Production }\end{array}$ & Millet Production & Rice Production & $\begin{array}{c}\text { Wheat } \\
\text { Production }\end{array}$ & $\begin{array}{c}\text { Barley } \\
\text { Production }\end{array}$ & Fonio Production \\
\hline $\begin{array}{l}\text { GDP per capita } \\
\text { growth }\end{array}$ & $\begin{array}{c}0.9851934^{* * *} \\
(4.12)\end{array}$ & $\begin{array}{c}6623.565^{* * *} \\
{[2.74]}\end{array}$ & $\begin{array}{c}2369.321 \\
(2.18)\end{array}$ & $\begin{array}{c}1372.234 \\
(1.62)\end{array}$ & $\begin{array}{c}-645.8084 \\
{[-0.42]}\end{array}$ & $\begin{array}{c}15,459.38^{* * *} \\
{[2.75]}\end{array}$ & $\begin{array}{c}42,489.02^{* * *} \\
{[4.30]}\end{array}$ & $\begin{array}{c}-775.6227 \\
(-0.64)\end{array}$ \\
\hline $\begin{array}{c}\text { Educational } \\
\text { Inequality, Gini }\end{array}$ & $\begin{array}{c}-1.605586^{* * *} \\
(-4.97)\end{array}$ & $\begin{array}{c}-20,892.1 * * * \\
{[-10.16]}\end{array}$ & $\begin{array}{c}-4520.574^{* * * *} \\
(-4.98)\end{array}$ & $\begin{array}{c}-4523.103^{* * *} \\
(-5.85)\end{array}$ & $\begin{array}{c}-11,114.77^{* * *} \\
{[-4.99]}\end{array}$ & $\begin{array}{c}-10,901.36 * * \\
{[-2.16]}\end{array}$ & $\begin{array}{c}10845.18 \\
{[1.36]}\end{array}$ & $\begin{array}{c}-6237.34^{* * *} \\
(-7.90)\end{array}$ \\
\hline $\begin{array}{l}\text { Number of People } \\
\text { Affected by Flood }\end{array}$ & $\begin{array}{c}54.60008 \\
(0.50)\end{array}$ & $\begin{array}{c}-55925.41 \\
{[-0.07]}\end{array}$ & $\begin{array}{c}-5490.607 \\
(-0.02)\end{array}$ & $\begin{array}{c}-1908.055 \\
(-0.01)\end{array}$ & $\begin{array}{c}-518772.2 \\
{[-0.64]}\end{array}$ & $\begin{array}{c}-1131083 \\
{[-0.57]}\end{array}$ & $\begin{array}{c}3,794,894 \\
{[0.32]}\end{array}$ & $\begin{array}{c}-313,625.6 \\
(-1.02)\end{array}$ \\
\hline $\begin{array}{l}\text { Number of People } \\
\text { Affected by Drought }\end{array}$ & $\begin{array}{l}-31.99213 \\
(-1.39)\end{array}$ & $\begin{array}{c}-552,229.11^{* * *} \\
{[-3.75]}\end{array}$ & $\begin{array}{l}-61,476.59 \\
(-1.04)\end{array}$ & $\begin{array}{l}-74,580.37 \\
\quad(-1.21)\end{array}$ & $\begin{array}{c}-1235.48 \\
{[-0.01]}\end{array}$ & $\begin{array}{c}48,256.81 \\
{[0.15]}\end{array}$ & $\begin{array}{c}64,481.36 \\
{[0.13]}\end{array}$ & $\begin{array}{c}86,418.55 \\
(0.77)\end{array}$ \\
\hline
\end{tabular}


Table 6. Cont.

\begin{tabular}{|c|c|c|c|c|c|c|c|c|}
\hline \multirow[b]{2}{*}{ Dependent Variable } & (1) & (2) & (3) & \multirow[b]{2}{*}{ Millet Production } & (5) & \multirow{2}{*}{$\begin{array}{c}\text { (6) } \\
\text { Wheat } \\
\text { Production }\end{array}$} & \multirow{2}{*}{$\begin{array}{c}\mathbf{( 7 )} \\
\text { Barley } \\
\text { Production }\end{array}$} & \multirow{2}{*}{\begin{tabular}{|c|} 
(8) \\
Fonio Production
\end{tabular}} \\
\hline & $\begin{array}{c}\text { Cereal } \\
\text { Production Index }\end{array}$ & Maize Production & $\begin{array}{l}\text { Sorghum } \\
\text { Production }\end{array}$ & & Rice Production & & & \\
\hline $\begin{array}{l}\text { Number of People } \\
\text { Affected by Storm }\end{array}$ & $\begin{array}{c}-0.000008 \\
(-0.50)\end{array}$ & $\begin{array}{c}-0.119833 \\
{[-1.37]}\end{array}$ & $\begin{array}{c}-0.0115932 \\
(-0.33)\end{array}$ & $\begin{array}{c}0.000002 \\
(0.00)\end{array}$ & $\begin{array}{l}0.0225578 \\
{[0.25]}\end{array}$ & $\begin{array}{c}0.0035995 \\
{[0.02]}\end{array}$ & $\begin{array}{c}-5.263566 \\
{[-0.90]}\end{array}$ & $\begin{array}{c}-66.31653 \\
(-1.54)\end{array}$ \\
\hline Cereal Food Aid & $\begin{array}{l}-0.000033^{* * *} \\
(-2.14)\end{array}$ & $\begin{array}{c}-0.94005^{* * *} \\
{[-10.41]}\end{array}$ & $\begin{array}{l}-0.073275^{* *} \\
(-2.00)\end{array}$ & $\begin{array}{l}0.1050056^{*} \\
(1.74)\end{array}$ & $\begin{array}{c}-1.45745^{* * *} \\
{[-15.80]}\end{array}$ & $\begin{array}{c}-1.6366^{* * *} \\
{[-8.37]}\end{array}$ & $\begin{array}{c}-0.0561999 \\
{[-0.30]}\end{array}$ & $\begin{array}{l}0.1900641 \\
\quad(0.71)\end{array}$ \\
\hline Constant & $\begin{array}{l}177.215^{* * *} \\
(10.77)\end{array}$ & $\begin{array}{c}1,782,212 * * * * \\
{[10.82]}\end{array}$ & $\begin{array}{l}458,177.8^{* * * *} \\
(9.45)\end{array}$ & $\begin{array}{l}403,646.2^{* * *} \\
(9.17)\end{array}$ & $\begin{array}{c}1,150,479 * * * \\
{[5.83]}\end{array}$ & $\begin{array}{c}1,287,005^{* * *} \\
{[3.85]}\end{array}$ & $\begin{array}{c}-120,938.3 \\
{[-0.25]}\end{array}$ & $\begin{array}{l}535,114.8^{* * * *} \\
(8.68)\end{array}$ \\
\hline $\begin{array}{c}N \\
\text { Type of Regression }\end{array}$ & $\begin{array}{l}952 \\
\text { FE }\end{array}$ & $\begin{array}{l}631 \\
\mathrm{RE}\end{array}$ & $\begin{array}{l}540 \\
\mathrm{FE}\end{array}$ & $\begin{array}{c}457 \\
\mathrm{FE}\end{array}$ & $\begin{array}{l}598 \\
\mathrm{RE}\end{array}$ & $\begin{array}{l}401 \\
\mathrm{RE}\end{array}$ & $\begin{array}{l}165 \\
\mathrm{RE}\end{array}$ & $\begin{array}{l}115 \\
\mathrm{FE}\end{array}$ \\
\hline \multicolumn{9}{|c|}{ Note: Numbers in brackets are $z$-values, and in parentheses are $t$-values; ${ }^{* * *}, * *$, and ${ }^{*}$ indicate statistical significance at the $1 \%, 5 \%$, and $10 \%$ levels, respectively. } \\
\hline \multirow{2}{*}{\multicolumn{2}{|c|}{ Dependent Variable }} & Poverty in Rural Area & \multicolumn{2}{|c|}{ Poverty in Urban Area } & rty in Urban Area & \multicolumn{2}{|c|}{ Battle Related Deaths } & le Related Deaths \\
\hline & & (1) & \multicolumn{2}{|c|}{ (2) } & (3) & (4) & & (5) \\
\hline \multicolumn{2}{|c|}{$\begin{array}{l}\text { Number of People Affected by } \\
\text { Climate-related Disasters }\end{array}$} & $\begin{array}{c}9.285749 \\
{[1.12]}\end{array}$ & \multicolumn{2}{|c|}{$\begin{array}{c}15.6348^{* *} \\
{[2.34]}\end{array}$} & & \multicolumn{2}{|c|}{$\begin{array}{l}11,854.74^{* * *} \\
(2.93)\end{array}$} & \\
\hline \multicolumn{3}{|c|}{ Number of People Affected by Flood } & \multicolumn{3}{|r|}{$\begin{array}{l}-64.6435 \\
(-1.50)\end{array}$} & & & $\begin{array}{l}12,956.34 \\
(0.57)\end{array}$ \\
\hline \multicolumn{2}{|c|}{$\begin{array}{c}\text { Number of People Affected by } \\
\text { Drought }\end{array}$} & & \multicolumn{3}{|r|}{$\begin{array}{l}20.16717^{* *} \\
\quad(2.57)\end{array}$} & & & $\begin{array}{c}13,122.96^{* * * *} \\
(3.89)\end{array}$ \\
\hline \multicolumn{2}{|c|}{ Number of People Affected by Storm } & & \multicolumn{3}{|r|}{$\begin{array}{c}-79.01091 \\
(-0.88)\end{array}$} & & & $\begin{array}{c}-0.0149493 \\
(-0.28)\end{array}$ \\
\hline \multicolumn{2}{|c|}{ Constant } & $\begin{array}{c}23.394^{* * *} \\
{[16.03]}\end{array}$ & \multicolumn{2}{|c|}{$\begin{array}{c}11.288^{* * *} \\
{[8.01]}\end{array}$} & $\begin{array}{c}12.342^{* * *} \\
(12.38)\end{array}$ & $\begin{array}{r}1142.126 \\
(3.91\end{array}$ & & $\begin{array}{c}1105.389 * * * \\
(3.77)\end{array}$ \\
\hline \multicolumn{2}{|l|}{$N$} & 77 & \multicolumn{2}{|c|}{76} & 75 & 260 & & 260 \\
\hline \multicolumn{2}{|c|}{ Type of Regression } & $\mathrm{RE}$ & \multicolumn{2}{|c|}{ RE } & FE & FE & & FE \\
\hline
\end{tabular}

Note: Numbers in parentheses are $t$-values; ${ }^{* * *}, * *$ and ${ }^{*}$ indicate statistical significance at the $1 \%, 5 \%$, and $10 \%$ levels, respectively. 
Amid armed conflicts, another possible outcome is reduced agricultural production. Models 4 and 5 studied the impact of natural disasters on the number of battle-related deaths. Using aggregate natural disaster data, Model 4 shows that while growth in GDP per capita reduced battle-related deaths, natural disasters significantly increased the death toll. Model 5 also confirmed this aspect. Among the types of natural disasters, droughts exacerbated battle-related deaths in Africa.

As these results indicate, natural disasters reduce agricultural production and trigger poverty and armed conflicts.

Finally, Table 8 examines the various factors that contributed toward reducing the number of deaths caused by climate-related natural disasters. This analysis aimed to explore how African countries can respond and mitigate the adverse effects of climate warming.

Table 8. Factors Contributed to Reduce the Number of Deaths by Disasters.

\begin{tabular}{|c|c|c|c|c|}
\hline \multirow{2}{*}{ Dependent Variable } & \multicolumn{4}{|c|}{ Total Number of Deaths by Climate-Related Disasters } \\
\hline & (1) & (2) & (3) & (4) \\
\hline HDI (Human Development Index) & $\begin{array}{c}-504.342 \\
(-1.31)\end{array}$ & $\begin{array}{c}-621.4799 \\
(-1.50)\end{array}$ & $\begin{array}{c}-349.3779 * \\
(-1.68)\end{array}$ & $\begin{array}{c}-354.2997^{*} \\
(-1.68)\end{array}$ \\
\hline Gov. Effectiveness & $\begin{array}{l}-131.8227 * * \\
(-2.37)\end{array}$ & $\begin{array}{l}-141.7638^{* *} \\
(-2.48)\end{array}$ & $\begin{array}{c}-54.9951 * \\
(-1.77)\end{array}$ & $\begin{array}{l}-55.76964 * \\
\quad(-1.76)\end{array}$ \\
\hline Control of Corruption & $\begin{array}{c}36.64476 \\
(0.60)\end{array}$ & $\begin{array}{c}20.4265 \\
(0.32)\end{array}$ & $\begin{array}{l}31.70747 \\
(0.96)\end{array}$ & $\begin{array}{l}31.43229 \\
(0.93)\end{array}$ \\
\hline Regulatory Quality & & $\begin{array}{c}49.01479 \\
(0.76)\end{array}$ & $\begin{array}{c}14.14797 \\
(0.48)\end{array}$ & $\begin{array}{c}13.79879 \\
(0.46)\end{array}$ \\
\hline $\begin{array}{l}\text { ODA for Disaster Prevention } \\
\text { and Preparedness }\end{array}$ & $\begin{array}{l}-0.000008^{* * *} \\
(-2.78)\end{array}$ & $\begin{array}{l}-0.0000073^{* * * *} \\
(-2.65)\end{array}$ & & \\
\hline Humanitarian ODA & & & $\begin{array}{c}-0.0000002 * * * \\
(-4.04)\end{array}$ & \\
\hline Emergency ODA & & & & $\begin{array}{l}-0.0000002^{* * *} \\
\quad(-4.16)\end{array}$ \\
\hline Constant & $\begin{array}{l}187.7321 \\
(1.05)\end{array}$ & $\begin{array}{l}254.3052 \\
\quad(1.28)\end{array}$ & $\begin{array}{l}181.7999 * \\
(1.74)\end{array}$ & $\begin{array}{l}181.3178 * \\
(1.73)\end{array}$ \\
\hline$N$ & 234 & 234 & 343 & 334 \\
\hline Type of Regression & $\mathrm{FE}$ & FE & FE & FE \\
\hline
\end{tabular}

Note: Numbers in brackets are $z$-values, and in parentheses are $t$-values; ${ }^{* * *},{ }^{* *}$, and ${ }^{*}$ indicate statistical significance at the $1 \%, 5 \%$, and $10 \%$ levels, respectively.

Model 1 examined HDI (Human Development Index), government effectiveness, and corruption control. Corruption control is a proxy for government transparency. Government effectiveness is strongly significant in reducing the number of disaster-related deaths. The ODA for disaster prevention and preparedness has also become positive. However, the coefficient is not necessarily large enough to mitigate the impact on deaths. Therefore, the government's capacity building is critical for mitigating the impact of natural disasters. Model 2 includes the regulatory quality of government policies, but the results do not change.

Model 4 tests humanitarian aid, and Model 5 includes emergency aid. Both are statistically significant in reducing the number of deaths caused by natural disasters. This is an excellent outcome for international donors, but it is necessary to note that the coefficients are very small. In other words, to mitigate damage caused by increasing climate-related disasters, these aids are inadequate for coping with the damage. From this analysis, it can be concluded that government effectiveness is key to reducing the number of deaths caused by natural disasters. 


\section{Conclusions}

Unlike previous studies, this study controlled for social variables and examined the crop-by-crop impact. Using panel data from African countries, this study found the following four aspects.

1. Climate-related natural disasters negatively impact per capita GDP growth and agricultural production. The impact is severe on cereal production, especially droughts (maize) and storms (rice and fonio).

2. While ODA for agriculture has a slightly positive impact, cereal aid food negatively impacts cereal production (maize, sorghum, rice, wheat).

3. Climate-related disasters, primarily droughts, increase poverty in urban areas and increase battle-related deaths. This result supports Burke et al.'s [41] argument.

4. Finally, government effectiveness is key to determining the number of deaths caused by climate-related disasters.

There are several important policy implications. First, these findings show that climate change has severe consequences not only for the development of African countries but also armed conflicts. As mentioned earlier, Africa is the least responsible for the increase in greenhouse emissions. Therefore, donor countries must initiate quick action to assist African countries and help them cope with climate change, especially climate-related natural disasters. Among natural disasters that are closely associated with human life, droughts have severe consequences on the following socio-economic activities: GDP per capita growth, agricultural production, poverty, and armed conflicts. International donors must focus on developing measures to prevent droughts and assist African countries' adaptive strategies to combat global warming.

Second, government effectiveness is key to coping with climate-related disasters. International aid must be provided to improve effectiveness. This is clear, as the coefficient of the impact to reduce the number of deaths was small on ODA for disaster prevention and preparedness, humanitarian ODA, and emergency ODA.

Third, there is a need to review if cereal aid is beneficial for African countries as it reduces cereal production, possibly due to a crowding-out effect on domestic production.

As discussed in Section 2, disaster data may be underreported. Most authoritarian governments do not overemphasize the damage caused by natural disasters. These governments have a strong incentive to underreport damages. Thus, our assessment likely underestimates the true damage level. Therefore, it is necessary to plan policies and measures that consider this possibility.

Funding: This work was supported by JSPS KAKENHI Grant Number 18H03606 and a grant from the Institute of Social Sciences, Meiji University.

Institutional Review Board Statement: Not applicable.

Informed Consent Statement: Not applicable.

Data Availability Statement: The data that support the study findings are available from Go Shimada. Restrictions apply to the availability of these data, as they are used under license for this study.

Acknowledgments: I sincerely appreciate Shinya Konaka and Toru Yanagihara for their comments on an earlier version of this study. The author is solely responsible for any errors or inaccuracies reported.

Conflicts of Interest: The author declares that he has no known competing financial interest or personal relationships that could have influenced the work reported in this study. 


\section{Appendix A}

Table A1. Non-Cereal Crops.

\begin{tabular}{|c|c|c|c|c|}
\hline \multirow{2}{*}{ Dependent Variable } & (1) & (2) & (3) & (4) \\
\hline & Banana Production & Cassava Production & Tea Production & Coffee Production \\
\hline GDP per capita growth & $\begin{array}{c}-3964.216^{*} \\
(-1.87)\end{array}$ & $\begin{array}{c}-13,413.36 \\
{[-1.51]}\end{array}$ & $\begin{array}{c}493.2195 \\
{[0.98]}\end{array}$ & $\begin{array}{c}87.8662 \\
{[0.26]}\end{array}$ \\
\hline $\begin{array}{l}\text { Educational Inequality, } \\
\text { Gini }\end{array}$ & $\begin{array}{l}-35,370.73^{* * * *} \\
(-7.14)\end{array}$ & $\begin{array}{c}-123,926.1^{* * *} \\
{[-5.87]}\end{array}$ & $\begin{array}{c}-1405.38 \\
{[-1.61]}\end{array}$ & $\begin{array}{c}623.709 \\
{[1.15]}\end{array}$ \\
\hline $\begin{array}{l}\text { Number of People Affected } \\
\text { by Flood }\end{array}$ & $\begin{array}{c}-172,524.4 \\
(-0.14)\end{array}$ & $\begin{array}{c}4,010,153 \\
{[0.69]}\end{array}$ & $\begin{array}{c}-157,908.5 \\
{[-0.60]}\end{array}$ & $\begin{array}{c}53,130.28 \\
{[0.26]}\end{array}$ \\
\hline $\begin{array}{c}\text { Number of People Affected } \\
\text { by Drought }\end{array}$ & $\begin{array}{c}117,739.9 \\
(0.59)\end{array}$ & $\begin{array}{c}-1,717,949 \\
{[-1.59]} \\
\end{array}$ & $\begin{array}{c}33,912.43 \\
{[1.46]}\end{array}$ & $\begin{array}{c}-81,737.55 * * \\
{[-2.08]}\end{array}$ \\
\hline $\begin{array}{l}\text { Number of People Affected } \\
\text { by Storm }\end{array}$ & $\begin{array}{c}0.0329793 \\
(0.25)\end{array}$ & $\begin{array}{c}-1.00887 \\
{[-1.63]}\end{array}$ & $\begin{array}{c}-0.0004288 \\
{[-0.04]}\end{array}$ & $\begin{array}{c}0.0114696 \\
{[0.55]}\end{array}$ \\
\hline ODA for Agriculture & $\begin{array}{c}0.0002185 \\
(0.45) \\
\end{array}$ & $\begin{array}{c}0.0047701^{* *} \\
{[2.15]}\end{array}$ & $\begin{array}{l}0.0001 \\
{[1.54]}\end{array}$ & $\begin{array}{c}-0.0000291 \\
{[-0.35]} \\
\end{array}$ \\
\hline Constant & $\begin{array}{c}2,052,232 \text { *** } \\
(8.55)\end{array}$ & $\begin{array}{c}9,049,5222^{* * *} \\
{[6.25]}\end{array}$ & $\begin{array}{c}106,277.7^{* *} \\
{[1.89]}\end{array}$ & $\begin{array}{c}2775.313 \\
{[0.10]} \\
\end{array}$ \\
\hline $\begin{array}{l}N \\
\text { Type of Regression }\end{array}$ & 197 & 188 & 80 & 144 \\
\hline Type of Regression & FE & RE & RE & FE \\
\hline
\end{tabular}

Note: Numbers in brackets are $z$-values, and in parentheses are $t$-values; ${ }^{* * *}, * *$ and ${ }^{*}$ indicate statistical significance at the $1 \%, 5 \%$, and $10 \%$ levels, respectively.

\section{References}

1. Centre for Research on the Epidemiology of Disasters. Extreme Weather Events in Europe. Cred Crunch 2021. Available online: https:/ / www.cred.be/publications (accessed on 1 September 2021).

2. Peduzzi, P.; Chatenoux, B.; Dao, H.; De Bono, A.; Herold, C.; Kossin, J.; Mouton, F.; Nordbeck, O. Global trends in tropical cyclone risk. Nat. Clim. Chang. 2012, 2, 289-294. [CrossRef]

3. Field, C.B.; Barros, V.R. Climate Change 2014-Impacts, Adaptation and Vulnerability: Regional Aspects; Cambridge University Press: Cambridge, UK, 2014.

4. Bernard, B.; Vincent, K.; Frank, M.; Anthony, E. Comparison of extreme weather events and streamflow from drought indices and a hydrological model in River Malaba, Eastern Uganda. Int. J. Environ. Stud. 2013, 70, 940-951. [CrossRef]

5. Tellman, B.; Sullivan, J.A.; Kuhn, C.; Kettner, A.J.; Doyle, C.S.; Brakenridge, G.R.; Erickson, T.A.; Slayback, D.A. Satellite imaging reveals increased proportion of population exposed to floods. Nature 2021, 596, 80-86. [CrossRef]

6. Kahn, M.E. The death toll from natural disasters: The role of income, geography, and institutions. Rev. Econ. Stat. 2005, 87, 271-284. [CrossRef]

7. Strömberg, D. Natural Disasters, Economic Development, and Humanitarian Aid. J. Econ. Perspect. 2007, 21, 199-222. [CrossRef]

8. Noy, I.; Vu, T.B. The economics of natural disasters in a developing country: The case of Vietnam. J. Asian Econ. 2010, 21, 345-354. [CrossRef]

9. Cavallo, E.A.; Noy, I. The Economics of Natural Disasters: A Survey. 2009. Available online: https://publications.iadb.org/en/ publication/economics-natural-disasters-survey (accessed on 4 October 2021).

10. Cavallo, E.; Galiani, S.; Noy, I.; Pantano, J. Catastrophic natural disasters and economic growth. Rev. Econ. Stat. 2013, 95, 1549-1561. [CrossRef]

11. Shimada, G. The macroeconomic impacts of natural disasters: A case study of Japan. GSAPs J. Grad. Sch. Asia Pac. Stud. 2012, 24, 121-137.

12. Noy, I. The macroeconomic consequences of disasters. J. Dev. Econ. 2009, 88, 221-231. [CrossRef]

13. Shimada, G. The role of social capital after disasters: An empirical study of Japan based on Time-Series-Cross-Section (TSCS) data from 1981 to 2012. Int. J. Disaster Risk Reduct. 2015, 14, 388-394. [CrossRef]

14. Benson, C.; Clay, E.J. Disasters, vulnerability and the global economy: Implications for less-developed countries and poor populations. In Developmental Entrepreneurship: Adversity, Risk, and Isolation; Emerald Group Publishing Limited: Bingley, UK, 2006.

15. Shimada, G. A quantitative study of social capital in the tertiary sector of Kobe-Has social capital promoted economic reconstruction since the Great Hanshin Awaji Earthquake? Int. J. Disaster Risk Reduct. 2017, 22, 494-502. [CrossRef] 
16. Rasmussen, T. Macroeconomic implications of natural disasters in the Caribbean WP/04.224. IMF Work. Pap. 2004, $2004,1-25$.

17. Albala-Bertrand, J. Political Economy of Large Natural Disasters: With Special Reference to Developing Countries; Oxford University Press: Oxford, UK, 1993; ISBN 0198287658.

18. Dacy, D.C.; Kunreuther, H. Economics of Natural Disasters; Implications for Federal Policy; Free Press: New York, NY, USA, 1969.

19. Toll, R.; Leek, F. Economic Analysis of Natural Disasters. In Climate Change and Risk; Downing, T., Olsthoorn, A., Tol, R.S., Eds.; Routledge: London, UK, 1999; pp. 308-327.

20. Skidmore, M.; Toya, H. Do natural disasters promote long-run growth? Econ. Inq. 2002, 40, 664-687. [CrossRef]

21. Sawada, Y.; Bhattcharyay, R.; Kotera, T. Aggregate Impacts of Natural and Man-Made Disasters: A Quantitative Comparison; Research Institute of Economy, Trade and Industry: Tokyo, Japan, 2011.

22. Charvériat, C. Natural disasters in Latin America and the Caribbean: An overview of risk. Inter-Am. Dev. Bank (IDB) Work. Pap. 2000, 434, 1-104. [CrossRef]

23. Hochrainer, S. Assessing the Macroeconomic Impacts of Natural Disasters: Are There Any; World Bank Policy Research Working Paper Series; The World Bank: Washington, DC, USA, 2009.

24. Vermeulen, S.J.; Aggarwal, P.K.; Ainslie, A.; Angelone, C.; Campbell, B.M.; Challinor, A.J.; Hansen, J.W.; Ingram, J.S.I.; Jarvis, A.; Kristjanson, P.; et al. Options for support to agriculture and food security under climate change. Environ. Sci. Politics 2012, 15, 136-144. [CrossRef]

25. Lesk, C.; Rowhani, P.; Ramankutty, N. Influence of extreme weather disasters on global crop production. Nature 2016, 529, 84-87. [CrossRef] [PubMed]

26. Connolly-Boutin, L.; Smit, B. Climate change, food security, and livelihoods in sub-Saharan Africa. Reg. Environ. Chang. 2016, 16, 385-399. [CrossRef]

27. Shimada, G.; Motomura, M. Building Resilience through Social Capital as a Counter-Measure to Natural Disasters in Africa: A Case Study from a Project in Pastoralist and Agro-Pastoralist Communities in Borena, in the Oromia Region of Ethiopia. Afr. Study Monogr. 2017, 53, 35-51.

28. Higuchi, Y.; Shimada, G. Industrial Policy, Industrial Development, and Structural Transformation in Asia and Africa. In Paths to the Emerging State in Asia and Africa; Otsuka, K., Sugihara, K., Eds.; Springer: Singapore, 2019; pp. 195-218.

29. Hosono, A.; Page, J.; Shimada, G. (Eds.) Workers, Managers, Productivity-Kaizen in Developing Countries; Palgrave Macmillan: Singapore, 2020.

30. Shimada, G.; Sonobe, T. Impacts of management training on workers: Evidence from Central America and the Caribbean region. Rev. Dev. Econ. 2021, 25, 1492-1514. [CrossRef]

31. Phiiri, G.K.; Egeru, A.; Ekwamu, A. Climate change and agriculture nexus in Sub-Saharan Africa: The agonizing reality for smallholder farmers. Int. J. Curr. Res. Rev. 2016, 8, 57.

32. Schultz, T.W. Transforming traditional agriculture. In Transforming Traditional Agriculture; University of Chicago Press: Chicago, IL, USA, 1964.

33. Schultz, T.W. Investment in human capital. Am. Econ. Rev. 1961, 51,1-17.

34. Cuny, F.C. Disasters and Development; Intertect Press: Dallas, TX, USA, 1994.

35. Raschky, P.; Schwindt, M. Aid, Natural Disasters and the Samaritan's Dilemma; World Bank Policy Research Working Paper Series; The World Bank: Washington, DC, USA, 2009. [CrossRef]

36. De Juan, A.; Pierskalla, J.; Schwarz, E. Natural disasters, aid distribution, and social conflict-Micro-level evidence from the 2015 earthquake in Nepal. World Dev. 2020, 126, 104715. [CrossRef]

37. Becerra, O.; Cavallo, E.; Noy, I. Foreign aid in the aftermath of large natural disasters. Rev. Dev. Econ. 2014, 18, 445-460. [CrossRef]

38. Andor, M.A.; Osberghaus, D.; Simora, M. Natural disasters and governmental aid: Is there a charity hazard? Ecol. Econ. 2020, 169, 106534. [CrossRef]

39. Barrett, C.B. Measuring food insecurity. Science 2010, 327, 825-828. [CrossRef]

40. O'Loughlin, J.; Linke, A.M.; Witmer, F.D. Effects of temperature and precipitation variability on the risk of violence in sub-Saharan Africa, 1980-2012. Proc. Natl. Acad. Sci. USA 2014, 111, 16712-16717. [CrossRef]

41. Burke, M.B.; Miguel, E.; Satyanath, S.; Dykema, J.A.; Lobell, D.B. Warming increases the risk of civil war in Africa. Proc. Natl. Acad. Sci. USA 2009, 106, 20670-20674. [CrossRef]

42. Buhaug, H. Climate not to blame for African civil wars. Proc. Natl. Acad. Sci. USA 2010, 107, 16477-16482. [CrossRef]

43. Burke, M.B.; Miguel, E.; Satyanath, S.; Dykema, J.A.; Lobell, D.B. Climate robustly linked to African civil war. Proc. Natl. Acad. Sci. USA 2010, 107, E185. [CrossRef]

44. Schultz, T.W. On Investing in Specialized Human Capital to Attain Increasing Returns; Oxford Blackwell: Oxford, UK, 1988.

45. The World Bank. World Development Indicators; The World Bank: Washington, DC, USA, 2021.

46. EM-DAT. The Emergency Events Database Université Catholique de Louvain (UCL)-CRED, D. Guha-Sapir; EM-DAT: Brussels, Belgium, 2021; Available online: http:/ / www.emdat.be (accessed on 1 September 2021).

47. Food Agriculture Organization of the United Nations. FAOSTAT Statistical Database; Food Agriculture Organization of the United Nations: Rome, Italy, 2021.

48. Coppedge, M.; Gerring, J.; Knutsen, C.H.; Lindberg, S.I.; Teorell, J.; Altman, D.; Bernhard, M.; Fish, M.S.; Glynn, A.; Hicken, A.; et al. V-Dem Codebook v9; The V-Dem Institute: Gothenburg, Sweden, 2019.

49. Jerven, M. Poor Numbers; Cornell University Press: Ithaca, NY, USA, 2013. 